\title{
DETERMINAN PENGGUNAAN PELAYANAN ANC DI NEGARA BERKEMBANG: TINJAUAN PUSTAKA TRADISIONAL
}

\section{Determinants Of ANC Utilization In Developing Country: Traditional Literature Review}

\author{
Helmi Nurlaili \\ ${ }^{*}$ Magister Ilmu Kesehatan Masyarakat, Universitas Sebelas Maret \\ e-mail: helminurlaili@gmail.com
}

\begin{abstract}
ABSTRAK
Latar Belakang: Angka Kematian Ibu (AKI) tahun 2015 mencapai 303.000 akibat komplikasi selama kehamilan dan persalinan dengan 99\% kejadian berada di negara berkembang. Komplikasi kehamilan tersebut dapat dicegah memalui perawatan selama kehamilan atau antenatal care (ANC). Minimnya penggunaan pelayanan ANC di negara berkembang disebabkan oleh disparitas yang terjadi akibat perbedaan geografis, demografis, sosioekonomi, dan budaya. Tinjauan pustaka ini bertujuan untuk mengidentifikasi determinan penggunaan pelayanan ANC di beberapa negara berkembang. Metode: Pencarian artikel dilakukan di basis data Scopus yang terbit tahun 2015-2019 dengan lokasi penelitian di negara berbagai berkembang.

Hasil: Terdapat berbagai artikel penelitian terkait faktor-faktor yang mempengaruhi penggunaan pelayanan ANC di negara berkembang. Penulis mengelompokkan menjadi dua kategori, yaitu berdasarkan karakteristik individu dan penyedia layanan ANC.

Kesimpulan: Tingkat pendidikan ibu hamil merupakan faktor yang paling berpengaruh diantara faktor lainnya. Tingkat pendidikan berhubungan positif terhadap penggunaan pelayanan ANC. Sedangkan faktor dominan dari penyedia layanan yaitu adanya fasilitas pelayanan ANC. Masih sedikitnya fasilitas kesehatan dan jauhnya jarak tempuh menjadi hambatan ibu hamil untuk melakukan kunjungan.
\end{abstract}

Kata kunci: pelayanan, antenatal care, faktor determinan 


\begin{abstract}
Background: The Maternal Mortality Rate (MMR) in 2015 reached 303,000 due to complications during pregnancy and childbirth with $99 \%$ deaths in developing countries. Complications of pregnancy can be prevented through treatment during pregnancy or antenatal care (ANC). The lack of ANC utilization in developing countries is caused by disparities that can occur due to differences in geographical, demographic, socioeconomic, and cultural. This literature review aims to identify determinants of ANC utilization in several developing countries.

Method: Article searching was conducted in the Scopus database published in 2015-2019 with research locations in various developing countries.

Results: There are various research articles related to the factors that influence the ANC utilization in developing countries. The author breaks down into two categories, based on individual characteristics and ANC service providers.

Conclusion: The education level of pregnant women is the most influential factor among others. It is positively related to the ANC utilization. While the dominant factor of service providers is the existence of ANC service facilities. The lack of health facilities and distance to travel are the obstacles for pregnant women to visit.
\end{abstract}

Keywords: service, antenatal care, determinants

\section{PENDAHULUAN}

Penurunan Angka Kematian Ibu (AKI) merupakan salah satu tujuan yang tercantum dalam Sustainable Development Goals (SDGs) bidang kesehatan ${ }^{[13]}$. Jumlah AKI pada tahun 2015 mencapai 303.000 atau sekitar 830 ibu meninggal setiap hari secara global akibat komplikasi selama kehamilan dan persalinan. Sekitar 99\% AKI terjadi di negara berkembang $^{[1,2]}$. Aborsi yang tidak aman, perdarahan, dan hipertensi kehamilan merupakan penyebab terbesar kematian ibu ${ }^{[3]}$. Komplikasi kehamilan tersebut dapat dicegah melalui perawatan yang sederhana dan hemat biaya selama kehamilan, persalinan, dan pasca melahirkan ${ }^{[2]}$.

Antenatal care (ANC) merupakan strategi utama untuk menurunkan morbiditas dan mortalitas ibu ${ }^{[4]}$. Tujuan ANC untuk memantau dan menjaga kesejahteraan ibu dan janin, mendeteksi segala komplikasi kehamilan dan mengambil tindakan yang diperlukan, menanggapi keluhan, mempersiapkan kelahiran, serta mempromosikan perilaku hidup sehat ${ }^{[2]}$. Kunjungan ANC dianggap penting dalam mendeteksi dan mencegah hal yang tidak diinginkan terkait kehamilan ${ }^{[5]}$.

World Health Organization (WHO) merekomendasi model focused antenatal care (FANC) sebagai standar perawatan yang terdiri dari minimal empat kunjungan selama kehamilan dengan kunjungan pertama pada trimester pertama. FANC dirancang sebagai kunjungan yang berkualitas tinggi, intensif, dan dipusatkan pada kebutuhan ibu ${ }^{[6,7]}$.

Di negara berkembang, penggunaan layanan kesehatan ibu telah meningkat namun masih terdapat variasi diantara kelompok populasi ${ }^{[8]}$. Disparitas dapat terjadi akibat perbedaan geografis, demografis, sosioekonomi, dan budaya ${ }^{[5,9]}$. Kesen-jangan yang terjadi dapat mengakibatkan menurunnya akses layanan, kualitas layanan, dan keterjangkauan layanan ${ }^{[8]}$. Tinjauan pustaka ini bertujuan untuk mengidentifikasi determinan penggunaan pelayanan ANC di beberapa negara berkembang.

\section{SUBJEK DAN METODE}

Pencarian artikel dilakukan di basis data Scopus menggunakan kata kunci: ('pre- 
dictors' OR 'determinants' OR 'factors affecting' OR 'measurements' Or 'dimensions' OR 'aspects' OR 'attributes') AND ('utilization' OR 'access' OR 'visit') AND ('antenatal care' OR 'pregnancy care' OR 'maternity care'). Artikel tersebut berupa penelitian asli dan tidak dipublikasikan dalam bentuk artikel ulasan atau laporan khusus. Kriteria artikel berupa penelitian kuantitatif, kualitatif, maupun mixed-method yang terbit tahun 20152019 dengan lokasi penelitian di negara berbagai berkembang.

\section{HASIL}

Penulis mengulas delapan artikel mengenai faktor penggunaan pelayanan ANC di negara berkembang, yaitu Etiopia, Nepal, Uganda, Korea, India, Yordania, dan Bangladesh. Artikel tersebut terdiri dari lima penelitian kuantitatif, dua penelitian kualitatif, dan satu penelitian mix-method.

Penulis mengidentifikasi 19 faktor yang selanjutnya dikelompokkan menjadi 2 kategori, yaitu berdasarkan karakteristik individu dan penyedia layanan ANC.

Tabel 1. Determinan penggunaan pelayanan ANC menurut beberapa artikel penelitian

\begin{tabular}{|c|c|c|c|c|c|c|c|c|c|}
\hline Determinan & Chi & Awasthi & Ayalew & Bobo & Mahapatro & Haque & Kim & Yeneneh & Hijazi \\
\hline Demografik & $\checkmark$ & & & & $\checkmark$ & & & $\checkmark$ & \\
\hline Pendidikan & $\checkmark$ & $\checkmark$ & $\checkmark$ & & & $\checkmark$ & $\checkmark$ & $\checkmark$ & $\checkmark$ \\
\hline Pekerjaan & $\checkmark$ & $\checkmark$ & & & & & & & \\
\hline Status ekonomi & $\checkmark$ & $\checkmark$ & & & & $\checkmark$ & & $\checkmark$ & \\
\hline Usia menikah & & $\checkmark$ & $\checkmark$ & & & & & $\checkmark$ & \\
\hline $\begin{array}{l}\text { Status } \\
\text { pernikahan }\end{array}$ & & & & & & & $\checkmark$ & & \\
\hline Kehamilan ke- & & $\checkmark$ & & & & & & $\checkmark$ & \\
\hline Jenis kehamilan & & & $\checkmark$ & & & & & & $\checkmark$ \\
\hline $\begin{array}{l}\text { Riwayat } \\
\text { kehamilan }\end{array}$ & $\checkmark$ & & $\checkmark$ & & & & & & \\
\hline $\begin{array}{l}\text { Struktur } \\
\text { keluarga }\end{array}$ & $\checkmark$ & $\checkmark$ & & & & & $\checkmark$ & & \\
\hline $\begin{array}{l}\text { Pengambil } \\
\text { keputusan }\end{array}$ & & $\checkmark$ & & & $\checkmark$ & & $\checkmark$ & & \\
\hline Kepercayaan & $\checkmark$ & $\checkmark$ & & & & & & & \\
\hline Stigma sosial & $\checkmark$ & & & & & & $\checkmark$ & & \\
\hline $\begin{array}{l}\text { Ketersediaan } \\
\text { fasilitas }\end{array}$ & $\checkmark$ & & & & & & & & $\checkmark$ \\
\hline $\begin{array}{l}\text { Pemberian } \\
\text { informasi }\end{array}$ & & & & & & & & & $\checkmark$ \\
\hline $\begin{array}{l}\text { Keterampilan } \\
\text { interpersonal }\end{array}$ & $\checkmark$ & & & & & & & & $\checkmark$ \\
\hline $\begin{array}{l}\text { Penjadwalan } \\
\text { kunjungan ulang }\end{array}$ & & & & & & & & & $\checkmark$ \\
\hline
\end{tabular}

1. Karakteristik Individu

a. Demografik

Karakteristik demografik dan wilayah tempat tinggal sangat mempengaruhi penggunaan pelayanan ANC. Masyarakat pedesaan lebih sering melakukan kunjungan ANC dibanding perkotaan ${ }^{[10]}$. Selain itu, status tempat tinggal juga berhubungan dengan frekuensi kunjungan ANC. Ibu hamil di negara konflik, seperti Burundi dan Uganda Utara merasa takut bepergian karena kondisi tempat tinggalnya yang tidak $\operatorname{aman}^{[9]}$.

b. Pendidikan

Tingkat pendidikan ibu hamil merupakan faktor yang paling berpengaruh. berbagai penelitian menyimpulkan semakin tinggi tingkat pendidikan maka semakin tinggi frekuensi kunjungan untuk pemeriksaan Antenatal Care ${ }^{[1,4-6,9-11]}$. 
c. Pekerjaan

Definisi pekerjaan tidak hanya ibu yang bekerja di luar rumah saja, termasuk juga beban pekerjaan di rumah meskipun berstatus sebagai ibu rumah tangga ${ }^{[9]}$.

d. Status ekonomi

Status ekonomi yang dimaksud adalah pendapatan keluarga. Aspek ini berhubungan positif dengan penggunaan pelayanan ANC. Semakin tinggi pendapatan maka semakin tinggi frekuensi kunjungan $\mathrm{ANC}^{[1,10]}$.

e. Usia pernikahan

Usia menikah termasuk juga usia hamil anak pertama ${ }^{[1]}$. Usia perempuan saat menikah dan hamil sangat mempengaruhi kunjungan ANC. Akan tetapi, terdapat perbedaan hubungan antar penelitian. Frekuensi kunjungan ANC ibu hamil berusia muda di etiopia lebih tinggi dibanding mereka yang berusia lebih tinggi ${ }^{[10]}$. Bukti ini berlainan dengan dua penelitian lain yang menyebutkan ibu hamil berusia $\geq 35$ tahun lebih tinggi dibanding mereka yang berusia $\leq 24$ tahun dalam mengakses pelayanan $\mathrm{ANC}^{[1,6]}$.

f. Kehamilan ke-

Kehamilan saat ini apakah kehamilan anak pertama atau sudah pernah hamil sebelumnya. Aspek ini memiliki hubungan yang berbanding terbalik dengan frekuensi kunjungan ANC. Semakin tinggi tingkat kehamilan maka semakin sedikit jumlah kunjungan $\mathrm{ANC}^{[10]}$.

g. Jenis kehamilan

Kehamilan yang dimaksud dikelompoknya menjadi kehamilan yang direncanakan atau tidak direncanakan. Frekuensi kunjungan ANC ibu dengan kehamilan yang direncanakan lebih tinggi daripada yang tidak ${ }^{[4,6]}$.

h. Riwayat kehamilan

Frekuensi kunjungan Ibu hamil yang memiliki pengalaman kurang baik pada kehamilan sebelumnya lebih tinggi dibanding mereka yang riwayat kehamilannya baik ${ }^{[6]}$.

i. Status pernikahan

Status pernikahan meliputi telah menikah sah atau belum menikah. Perempuan hamil yang belum menikah akan lebih sedikit dalam hal kunjungan ANCnya ${ }^{[11]}$.

j. Struktur keluarga

Di beberapa daerah, perempuan hamil tinggal dengan mertua sehingga peran ibu mertua sangat berpengaruh pada penggunaan layanan ANC. Faktor ini dianggap kurang jelas karena hasil penelitian saling berkebalikan. Ibu mertua dapat mendukung ibu hamil untuk melakukan kunjungan ANC dan sebaliknya ${ }^{[1,9,11]}$.

k. Pengambil keputusan

Sebagian besar pengambil keputusan rumah tangga adalah suami ${ }^{[11]}$. Jika ibu hamil tinggal bersama keluarga suami maka keputusan diambil oleh mertua ${ }^{[1]}$. Aspek ini berbeda tergantung pandangan mertua terkait kehamilan.

1. Kepercayaan

Kepercayaan berhubungan dengan kebudayaan. Di beberapa daerah, masyarakat lebih memilih untuk mencari perawatan ke tabib/ dukun $^{[1]}$.

m. Stigma sosial

Penilaian masyarakat sangat mempengaruhi perilaku ibu hamil. Di daerah tertentu atau pedesaan, masih terdapat anggapan negatif mengenai kehamilan sehingga ibu hamil enggan untuk memeriksakan kehamilannya ${ }^{[9,11]}$.

2. Penyedia layanan ANC

a. Ketersediaan fasilitas

Adanya berbagai fasilitas yang mendukung terselenggaranya kegiatan ANC dapat meningkatkan kunjungan ibu hamil ${ }^{[4,9]}$.

b. Pemberian informasi

Minat kunjungan ANC ibu hamil dapat meningkat dengan adanya pemberian berbagai informasi kesehat- 
an terutama kehamilan selama proses pemeriksaan dan pelayanan $\mathrm{ANC}^{[4]}$.

c. Kejelasan informasi

Informasi yang diberikan oleh tenaga kesehatan saat melakukan ANC hendaknya jelas dan mudah dipahami sehingga dapat diterima ibu hamil. Hal ini dapat meningkatkan minat ibu melakukan kunjungan $\mathrm{ANC}^{[4]}$.

d. Keterampilan interpersonal

Keterampilan interpersonal setiap pemberi pelayanan ANC sangat mempengaruhi ibu hamil. Pegawai dengan sikap/perilaku yang ramah terhadap ibu hamil akan berdampak positif terhadap jumlah kunjungan ANC ibu hamil ${ }^{[4]}$.

e. Penjadwalan kunjungan ulang Ibu hamil akan lebih patuh dan teratur dalam melakukan pemeriksaan kehamilannya apabila terdapat instruksi kapan dia harus datang kembali $^{[4]}$.

\section{PEMBAHASAN}

Karakteristik demografi negara berkembang bervariasi meliputi dataran, bukit, rawa, hutan, serta pesisir ${ }^{[5]}$. Sedikitnya jumlah fasilitas kesehatan berhubungan dengan jarak yang harus ditempuh untuk melakukan ANC. Transportasi umum yang belum memadai membuat ibu hamil kesulitan mengakses ${ }^{[5,12]}$. Selain itu, jauhnya fasilitas kesehatan berpengaruh pada jumlah uang yang dikeluarkan ${ }^{[4]}$. Hal yang sama juga dialami ibu hamil yang berada di daerah konflk. Selain ketakutan yang dirasakan saat bepergian; kurangnya tenaga kesehatan, infrastruktur, peralatan, dan obat mempengaruhi penggunaan layanan $\mathrm{ANC}^{[9]}$.

Ibu hamil yang berpendidikan lebih sadar terhadap kesehatannya dan keluar$\mathrm{ga}^{[1]}$. Mereka menyadari manfaat ANC bagi kehamilannya serta mampu mengidentifikasi tanda bahaya dan dapat dengan mudah memahami konsekuensi akibat tidak menghadiri layanan ANC yang direkome- ndasikan $^{[4,6]}$. Masyarakat dengan tingkat pendidikan rendah terbatas pada penggunaan bahasa. Tenaga kesehatan dapat memberikan penjelasan menggunakan lembar balik yang berisi gambar-gambar pendukung atau alat bantu lainnya ${ }^{[11]}$.

Ibu yang fokus dengan pekerjaannya merasa tidak memiliki waktu untuk mengunjungi fasilitas kesehatan. Hal yang sama juga terjadi pada ibu rumah tangga dimana pekerjaan seperti mencuci ataupun mengurus anak dianggap sebagai salah satu hambatan dalam mengakses pelayanan $\mathrm{ANC}^{[9]}$.

Ibu hamil dengan status ekonomi yang tinggi memiliki kemudahan mengakses informasi mengenai kehamilan melalui berbagai media, seperti televisi ${ }^{[11]}$. Selain itu, terbatasnya pendapatan berhubungan dengan biaya transportasi menuju fasilitas kesehatan $^{[9]}$.

Menikah dan hamil di usia muda dapat meningkatkan risiko keguguran serta komplikasi obstetri lainnya selama dan setelah kehamilan. Struktur organ tubuh perempuan usia muda yang belum matang. Hal inilah yang mendorong ibu hamil usia muda lebih tinggi dalam penggunaan pelayanan $\mathrm{ANC}^{[1]}$. Di Etiopia, meningkatnya usia ibu hamil berarti semakin banyak pengetahuan, pemahaman, dan pengalaman terkait kehamilan dan komplikasinya sehingga frekuensi kunjungan ANC mereka lebih tinggi dibanding ibu hamil usia muda $^{[6]}$.

Ibu dengan kehamilan pertama belum memiliki pengalaman maupun pengetahuan mengenai risiko dan komplikasi kehamilan. Oleh karena itu, mereka memanfaatkan kunjungan ANC sebagai sarana untuk memperoleh informasi ${ }^{[10]}$.

Ibu dengan kehamilan yang direncanakan menginginkan kehamilan yang sehat sehingga mereka memberikan perhatian penuh untuk pelayanan $\mathrm{ANC}^{[6]}$. Sebaliknya, kehamilan yang tidak direncanakan mengindikasikan kurangnya akses pendidikan keluarga berencana selama kunjungan $\mathrm{ANC}^{[4]}$. 
Ibu hamil yang pernah melahirkan bayi namun meninggal akan lebih tinggi dalam menggunakan pelayanan ANC. Mereka telah mengetahui risiko atas pengalamannya dan untuk mencegah hal tersebut terjadi kembali, mereka meningkatkan frekuensi kunjungan $\mathrm{ANC}^{[6]}$.

Ibu hamil yang tidak menikah takut atas penilaian masyarakat sehingga mereka merahasiakan kehamilannya dan tidak memeriksakannya ke fasilitas keseha$\tan ^{[11]}$.

Penelitian di Nepal menunjukkan bahwa ibu hamil yang tinggal bersama keluarga suami dan memiliki hubungan baik dengan ibu mertua berpengaruh pada tingginya rata-rata penggunaan pelayanan ANC selama kehamilan ${ }^{[1]}$. Selain itu, tanggung jawab suami dalam mencari nafkah membuatnya merasa kesulitan untuk merawat istrinya. Di sinilah peran ibu mertua untuk mendukung pemeriksaan kehamilan $^{[11]}$. Sebaliknya, masih terdapat kepercayaan tradisional mertua yang menganggap bahwa kehamilan merupakan kondisi normal sehingga tidak memerlukan pemeriksaan kesehatan tambahan ${ }^{[1]}$.

Perempuan hanya memiliki sedikit pilihan dalam keluarga sehingga mereka bergantung pada suami atau mertua dalam pengambilan keputusan termasuk pemeriksaan kehamilan. Penting bagi ibu hamil untuk menentukan pilihan dan keputusan mereka sendiri berdasarkan informasi yang dimiliki sesuai kebutuhannya ${ }^{[1]}$.

Masyarakat pedesaan masih percaya dan lebih memilih mencari penyembuhan tradisional dibanding tenaga kesehatan. Kepercayaan tersebut merupakan suatu perilaku sosial yang diwariskan turun temurun antar generasi dari leluhurnya ${ }^{[1]}$. Selain itu, masyarakat meyakini bahwa kehamilan merupakan kondisi normal sehingga tidak perlu memeriksakannya ${ }^{[9]}$.

Salah satu anggapan negatif masyarakat terkait kehamilan adalah terjadinya keguguran. Hal inilah yang membuat ibu hamil menyembunyikan kehamilannya di trimester awal, termasuk memeriksakannya ke fasilitas kesehatan ${ }^{[11]}$.
Kurangnya informasi yang dimiliki ibu hamil terkait komplikasi kehamilan merupakan alasan tidak memeriksakan kehamilannya ${ }^{[1]}$. Bagi mereka dengan akses rendah terhadap media, kunjungan ANC dapat menjadi salah satu cara untuk mendapatkan informasi dari tenaga kesehat$a^{[11]}$. Penyampaian informasi kepada ibu hamil secara jelas dan mudah dipahami dapat menyadarkan ibu akan pentingnya kunjungan ANC bagi kehamilannya ${ }^{[4]}$.

Perlu terciptanya hubungan baik antara ibu hamil dan tenaga kesehatan selama pemeriksaan ANC. Keterampilan komunikasi maupun interpersonal sangat dibutuhkan. Sikap tenaga kesehatan yang kasar atau menilai ibu hamil berdasarkan fisik/penampilan membuat ibu kurang nyaman. Hal ini dapat mempengaruhi jumlah kunjungan $\mathrm{ANC}^{[4,9]}$.

Tenaga kesehatan memiliki kewenangan dan saran mereka dipercaya oleh ibu hamil. Oleh karena itu, arahan terkait kunjungan ulang saat pemeriksaan ANC merupakan strategi untuk meningkatkan frekuensi kunjungan $\mathrm{ANC}^{[4]}$.

\section{KESIMPULAN}

Ada berbagai faktor determinan dalam penggunaan pelayanan ANC di negara berkembang. Faktor tersebut tidak hanya berasal dari individu ibu hamil namun juga berkaitan dengan pemberi layanan. Tingkat pendidikan ibu hamil merupakan faktor yang paling berpengaruh diantara faktor lainnya. Tingkat pendidikan berhubungan positif terhadap penggunaan pelayanan ANC. Semakin tinggi tingkat pendidikan ibu hamil maka semakin tinggi pula frekuensi kunjungan ANCnya. Sedangkan faktor dari penyedia layanan yaitu adanya fasilitas pelayanan ANC. Masih sedikitnya fasilitas kesehatan dan jauhnya jarak tempuh menjadi hambatan ibu hamil untuk melakukan kunjungan.

\section{DAFTAR PUSTAKA}

1. Awasthi MS, Awasthi KR, Thapa HS, Saud B, Pradhan S, Khatry RA. 
Utilization of Antenatal Care Services in Dalit Communities in Gorkha, Nepal: A Cross-Sectional Study. J Pregnancy. 2018;2018:1-8.

2. Islam MM, Masud MS. Determinants of frequency and contents of antenatal care visits in Bangladesh: Assessing the extent of compliance with the WHO recommendations. PLoS One. 2018;13(9):1-22.

3. Munguambe K, Boene H, Vidler M, Bique C, Sawchuck D, Firoz T, et al. Barriers and facilitators to health care seeking behaviours in pregnancy in rural communities of southern Mozambique. Reprod Health. 2016;13(Suppl 1):83-97.

4. Hijazi HH, Alyahya MS, Sindiani AM, Saqan RS, Okour AM. Determinants of antenatal care attendance among women residing in highly disadvantaged communities in northern Jordan: a cross-sectional study. Reprod Health. 2018;15(106):1-18.

5. Haque A, Dash SK, Chowdhury MAB. Maternal health care seeking behavior: the case of Haor (wetland) in Bangladesh. BMC Public Health. 2016;16(592):1-9.

6. Ayalew TW, Nigatu AM. Focused antenatal care utilization and associated factors in Debre Tabor Town, northwest Ethiopia, 2017. BMC Res Notes. 2018;11(819):1-6.

7. Patil CL, Klima CS, Leshabari SC, Steffen AD, Pauls H, Mcgown M, et al. Randomized controlled pilot of a group antenatal care model and the sociodemographic factors associated with pregnancy-related empowerment in sub- Saharan Africa. BMC Pregnancy Childbirth. 2017;17(Suppl 2(336):1-10.

8. Bobo FT, Yesuf EA, Woldie M. Inequities in utilization of reproductive and maternal health services in Ethiopia. Int $\mathbf{J}$ Equity Health. 2017;16(105):1-8.

9. Chi PC, Bulage P, Urdal H, Sundby J. A qualitative study exploring the determinants of maternal health service uptake in post-conflict Burundi and Northern Uganda. BMC Pregnancy Childbirth. 2015;15(18):114.

10. Yeneneh A, Alemu K, Dadi AF, Alamirrew A. Spatial distribution of antenatal care utilization and associated factors in Ethiopia : evidence from Ethiopian demographic health surveys. 2018;112.

11. Kim KH, Choi JW, Oh J, Moon J. What are the Barriers to Antenatal Care Utilization in Rufisque District , Senegal ?: a Bottleneck Analysis. 2019;34(7):1-19.

12. Mahapatro M. Equity in utilization of health care services: Perspective of pregnant women in southern Odisha, India. 2015;(August):183-9.

13. United Nations Development Programme. 2019. Goal 3: Good health and well-being. https://www.undp.org/content/undp/e n/home/sustainable-developmentgoals/goal-3-good-health-and-wellbeing.html. 9 April 2019. 